\title{
Mobile Games for Negotiated-Play and Decision-Making in Health Literacy
}

\author{
Sotiris Themistokleous ${ }^{1}$, Lucy Avraamidou ${ }^{2 *}$, Charalambos Vrasidas ${ }^{3}$ \\ ${ }^{1}$ Center for Social Innovation, CYPRUS \\ 2 University of Groningen, NETHERLANDS \\ ${ }^{3}$ CARDET - University of Nicosia, Nicosia, CYPRUS
}

Received 21 April 2020 - Accepted 10 June 2020

\begin{abstract}
The purpose of this qualitative case study study is to examine the ways in which mobile videogames can be used in non-formal educational environments, to support students to develop decision-making skills through negotiated play. In the context of this study, the health literacy mobile videogame, PlayForward: Elm City Stories developed at Yale University was implemented in an afterschool setting in southern Europe. In this study we explored how secondary school students negotiate meaning, make decisions, and interpret the consequences in a non-formal education context, through an interpretive symbolic-interactive framework. The data included individual interviews with students, field-notes, and video-based student-groups' interactions. These were analyzed with the use of open coding techniques. The analysis of the data resulted in the following three assertions: (a) The technical affordances of the game such as sound, usability, rating system, and visuals, are vital features that defined the quality of play and learning experience; (b) The narrative of the game guided the learning game-play experience of the students; and, (c) Students perceived that their engagement in the game facilitated their collaboration and decision-making. These are discussed alongside recommendations for game design for supporting negotiated play and decision-making.
\end{abstract}

Keywords: mobile games, healthy literacy, negotiated-play, decision-making

\section{INTRODUCTION}

According to the World Health Organization, health literacy is the nexus of "social and cognitive skills" which define the capacity of persons to access and manage health related information through active interaction, participation and critical analysis (World Health Organization, 2013). Health literacy goes well beyond information provision and knowledge development and into skills development, social interaction, and critical understanding, through active participation in the wider socioeconomic context. Broadly defined, health literacy is the ability of a person to be engaged in informed collaboration, communication and collective decision-making (Hernandez, 2013). However, a review of related literature shows that young people remain detached from core social and health literacy skills associated with their low capacity to take informed decisions, which leads to increased exposure to addictions and health risks (Hieftje, Duncan,
\& Fiellin, 2014). Also, another set of studies provides evidence that policy makers, school leaders and teachers either neglect the multidimensional social aspects of health literacy, or place the emphasis on incorporating health literacy in formal contexts, which keeps it fragmented from the wider civic ecosystem. An approach to this challenge, which is the basis of this study, lays within the use of mobile videogames in nonformal education settings, to advance students' health literacy and associated skills (i.e., critical thinking, collaboration, decision-making), in contextualized environments.

This study addresses health literacy in the wider context of skills development. Skills that are vital for health literacy, include critical thinking, that is, the ability to assess, analyze and reflect on information and practices, acquiring organizational skills to develop networks and collaborations, communication and negotiation skills to make decisions and solve problems (Montgomery, Gottlieb-Robles, \& Larson, 2004).

(c) 2020 by the authors; licensee Modestum. This article is an open access article distributed under the terms and conditions of the Creative Commons Attribution License (http://creativecommons.org/licenses/by/4.0/).

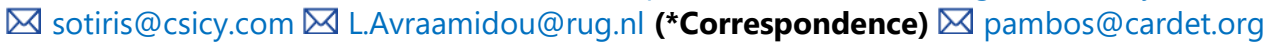




\section{Contribution to the literature}

- The study provides a concrete example of a mobile game implementation aiming to promote health literacy in the context of an after-school secondary education program.

- The technical affordances of the game such as sound, usability, rating system, and visuals, are vital features of the quality of play and learning experience.

- The narrative of the game is crucial in guiding the learning game-play experience supporting students collaboration and decision-making.

However, there exists only a limited number of studies that address young people's skills related to health literacy (Arnab, Brown, Clarke, Dunwell, Lim, Suttie, Louchart, Hendrix, \& De Freitas, 2013). In order to address this gap in the literature, the purpose of this study is to examine opportunities and challenges of the use of mobile videogames, particularly, the PlayForward: Elm City Stories in supporting students develop decisionmaking skills through collaborative play, associated with health literacy. Specifically, in this study we examine the use of the game on i-Pads in an after-school setting, in supporting young students to develop their health literacy skills, explore their collaborative decision-making process, and investigate, from an ethnographic, interpretive, and symbolically interactive framework the social processes that take place during their play. Thus, the following research questions are used to frame the design of this study:

(a) What are the potentials and challenges of using mobile videogames for promoting health literacy?

(b) What are students' perceptions of their skills acquisition through their engagement in mobile videogaming?

\section{The Role of Mobile Games in Education}

In various forms, games are part of everyday life of every human (Lenhart, Kahne, Middaugh, Macgill, Evans, \& Vitak, 2008). Games, as learning environments, evolved rapidly during the last decades, along with the constructivist perspective on education (Cunningham \& Duffy, 1996), the rapid spread of the web, social networks and mobile devices (Martin, Diaz, Sancristobal, Gil, Castro, \& Peire, 2011). A review of related literature indicates that mobile videogames are engaging for the youth, offering them greater levels of collaboration, discourse and creativity, which they would not experience within traditional learning environments, or even through static computers (Hense \& Mandl, 2014). Mobile videogames are attached to the contemporary flexibility of access, interaction, acquisition and meaning-making of information and knowledge, through gamified environments, with the use of smart-devices also associated with current youth culture (Koutromanos \& Avraamidou, 2014; Park, 2011).

Mobile learning goes beyond the mechanical use and utilization of mobile devices affordances; it's, more importantly, about the design of new learning environments, modes of knowledge design and delivery, and learning opportunities (Walker, 2006). The mobile nature of the practice and its tools, as well as the flexibility in its usage, secure the timeless and limitless access to information, its management, transformation and multiplication, making the learning process challenging, attractive and appealing (Kim, Mims, \& Holmes, 2006).

For students, the use of mobile devices in the learning process is an escape gate from traditional forms of education, walls, time-schedules, framed curriculum, controlled communication and uncomfortable chairs, since they can transfer their learning process to a customized environment with contextualized content and visuals, open communication, collaboration and experimentation in an endless cyberspace, all from the comfort of their chosen location (Olson, 2010; Shin, Norris, \& Soloway, 2011). Game experiences can mirror daily routine scenarios, allow the provision of instant feedback, and be flexible in their flow. Games need to have real-life representations, and also an emphasis on the consequences following actions, where young gamers need to reflect upon the outcomes of their decisions (Blumberg, Almonte, Anthony \& Hashimoto, 2012). Gaming is based on interaction, collaboration, active and dynamic learning, and a non-formal educational process that is invaluable. Such activities can help users to dynamically engage in health literacy and skills development (Fuchslocher, Niesenhaus, \& Krämer, 2011). Games which are linked with health literacy and social contexts allow users to explore hitherto unattainable situations and learn from simulated experience, enhancing critical reflection on health risk circumstances and building skills for collective decision-making and critical thinking (Blumberg et al., 2013).

As illustrated above, a review of the literature provides evidence that games have the potential to support learning in various ways. These can be summarized into the following:

- Visualization and Contextualization of real-life learning conditions through the game play environment (Lankshear \& Knobel, 2011; Schugurensky \& Myers, 2008)

- Learning by doing, Experimentation and Creativity through the story-line and game challenges (Muntean, 2011) 
- Autonomous interaction in terms of time and space due to its mobile availability (Caroline Faure, \& Kelle, 2013)

- Social skills development, such as decisionmaking, networking and leadership through simulations and role-playing (Arnab et al., 2013; Raphael, Bachen, Lynn, Baldwin-Philippi \& McKee, 2010)

In the case study reported in this paper, we examine the implementation the Elms City Stories, developed by the play2PREVENT Lab (http://www.play2prevent. org/) of the School of Public Health of Yale University. The Elms City Stories resembles the life of a student, of which its character was built by the gamer. The student faces real-life challenges associated with social, health and wellbeing issues (e.g., skipping classes, taking drugs, unprotected sex, hanging out with strangers), which need to enter a decision-making process. The game character's decisions are reflected in the course of the game, helping the gamers to visualize how different choices bring different, positive, or negative results to their lives. Decision-making, critical thinking, trial and error, visualization and collaboration, are all skills which can be developed through this mobile videogame, and are essential for the young students real-life challenges (Fiellin, Hieftje, Edelman, \& Camenga, 2013). The game was developed for single play and was only tested based on quantitative data collected from the game mechanics. In our study, in a different country context, we tested it as collaborative-play of small groups of three students working on one ipad because we were interested in examining how the game supports negotiation of ideas. In order to examine the processes of these negotiations we adopted a qualitative case study approach that would allow shedding light on how students interacted with each other and the game, negotiated ideas and developed understandings about health literacy.

\section{THEORETICAL FRAMEWORK}

The use of mobile videogames in education has been linked with social constructivism, as students' learning experiences escalate in a progressive manner (scaffolding), where they deploy old and construct new knowledge (Hernandez, 2013). Social constructivism encompasses collaborative learning, a "social process" where participants also deploy old knowledge and develop new understanding through negotiations and discussions with peers (Kearney, Schuck, Aubusson, \& Burden, 2013). Collaboration has strong elements of negotiations and meaning-sharing, which requires a set of skills to be beneficial as a learning process (Mishra, 2014). Therefore, in the context of implementing a game case study, we were interested in investigating the impact of the groups' negotiated play and, eventually, decision-making process, on students' skills development (Olson, 2010). Decision-making requires, beyond a basic comprehension of technical and informational knowledge, skills to contextualize the knowledge. Students need to take the right path of choices and decisions, through information and opinion assessment and constant negotiation (Galotti, 2002). Therefore, in the study reported in this manuscript, we use the term 'negotiated play' as an extension of collaborative learning, which better describes the play process of a group (Naismith, Lonsdale, Vavoula, \& Sharples, 2004). In doing so, we pay attention to the ways in which students, through a dialogical process, negotiate their views and understandings with others to come to an agreement.

\section{METHODS}

The study adopts a single case study design, examining a phenomenon in its natural setting, employing multiple methods of data collection to gather information from one or a few entities (Merriam, 2009). The case is defined by a group of students (13-15 years old) and the phenomenon under study is their experiences as members of a negotiated play of a mobile video game about health literacy.

The Elms City Stories mobile videogame resembles the life of a student, whose character was built by the gamer. The student faces real-life challenges associated with social, health and wellbeing issues (skipping classes, taking drugs, unprotected sex, hanging out with strangers) which to enter a decision-making process (Fiellin, Hieftje, \& Edelman, 2013). Montanaro, Fiellin, Fakhouri, Kyriakides, amd Duncan (2015) offered a description of the main narrative of the game:

\begin{abstract}
The main narrative of the game is comprised of 'challenge stack' levels in which players travel through a virtual life from grades 7 to 12 and engage in roleplaying scenarios where they must make decisions around risky behaviors (e.g., unprotected sex, alcohol use) and experience the positive and negative consequences of those behaviors. The players encounter realistic stories experienced by students, such as sneaking into a significant other's house, unplanned pregnancy, vandalism, and drunk driving. Players must also earn points in mini-games designed to build knowledge or behavioral skills needed to avoid risk, such as refusal, negotiation, or peer-assessment skills. The players acquire risk-related knowledge, navigate peer relationships, and negotiate against peer pressure. Through these mini-games, players acquire the 'senses' and 'powers' needed to resolve the stories ( $p .3)$.
\end{abstract}

It is apparent from the game description that the game is based on developing decision-making skills to navigate through challenges. This approach is also evident in the PlayForward Implementation Guide where players are encouraged to consider and reflect on their game-play based on the following questions: 
Table 1. Parallels in Research Questions and Data Source

Research Question Data Source

What are the potentials and challenges • Detailed analysis of game design and content

of using the PlayForward: Elm City

Stories mobile videogame for promoting health literacy in a nonformal educational context?
- Video-taped interactions of each groups of students (5 meetings x 1.5 hours)

- Field research notes

- Researcher's diary (6 diaries, 2 A4 long each)

Data were also used from:

- Post-Session Students' Statements

- post-implementation semi-structured interviews with each of the students (40 minutes long)

According to students' perceptions, what are the affordances of the PlayForward: Elm City Stories mobile videogame, which can facilitate or hinder collaborative decision- making skills development?

- Post-Session Students' Statements

- Post-implementation semi-structured interviews with each of the students (40 minutes long)

Data were also used from:

- Detailed analysis of game design and content

- Video-taped interactions of each groups of students (5 meetings x 1.5 hours)

- Field research notes

- Researcher's diary (6 diaries, 2 A4 long each)
Pause and Think: Why is it important to consider the possible positive and negative outcomes before making a decision? What are the benefits of doing this?

Can you think of a decision you made in your life of which you wish you had considered the consequences first?

\section{What might make your decision-making more difficult?}

Who might be affected by your decision?

The implementation was conducted in the afterschool hours for five weeks at two hours per week in a private school in a country in Southern Europe. The students were grouped in teams of three and played the game collaboratively, aiming to investigate and build their capacities in decision-making, negotiating and critical thinking. The play was repeatable, meaning that students worked in the same teams using the same ipad from the beginning until the end of the implementation in order to ensure both continuity and collaboration. Therefore, the unit that the case study research method investigated was the overall ecosystem of implementation with the five groups, three students each, the internal interactions with the game, between them and among the groups. To comply with ethical research requirements we obtained signed permission from the students' parents to use video recordings of the students' interactions and we also removed all names and any other identification of the students' identities. The data from the case study implementation collected were as shown in Table 1.

The data analysis included two stages, the inductive and the deductive (Stake, 2011). At the inductive stage, the data collected were coded and classified in categories, using open code techniques (Glaser, 1978). The analysis was done through open coding techniques by breaking data into distinct ideas and labeling any important information in the process taken from the content. Following that, the name of the labels was decided to form the in vivo codes. Open coding instead of axial coding was considered more profitable in this case study given that this is the first qualitative study done about the use of this game in the context of educational research. In addition, this method has the advantage of providing a "whole image" of the data, as the codes emerge from those instead of assigning preexisting codes with the risk of missing out other important information drawn out of the data.

In this context, as we were reading and re-reading the data, we attached labels/codes to them, which eventually resulted in the buildup of meaningful greater categories (Patton, 2002). Table 2 offers an example of the data coding.

As part of this process, and based on the higher-order categories and the codes, we developed assertions, which are statements that give a sense of generalization through data cross-analysis (i.e., the above category was qualified as an assertion/claim). At the deductive stage, there was a process of validating or rejecting the assertions. This process required a cross-checking between different categories, to identify overlaps or intersections of supportive or contradictive data, eventually validating, rejecting or merging the assertions. Assertions were only valued through a satisfactory number of data (researchers' notes and transcription quotes in our case), and sketched the overall framework of the research. In order to establish trustworthiness and minimize the subjectivity of the findings, this process was done by the first and second author in order to secure multiple perspectives which will appear in the data analysis, limit the domination of a one-sided approach, and contribute to the validity of the research.

A limitation of this study is associated with the fact that its findings cannot be generalized in the conventional paradigm. The findings, can, however, be transferred to similar out-of-school contexts, and with 
Table 2. Example from data-coding

\begin{tabular}{|c|c|c|}
\hline \multicolumn{3}{|l|}{ Category: Decision-Making Process } \\
\hline Quotes & Codes & Theme \\
\hline $\begin{array}{l}\text { In order to find the objective on your own without the help of somebody else because if } \\
\text { you play with } 2 \text { or more people, you may have some triple get into trouble. } \\
\text { Not actually making decisions. } \\
\text { If one person gets bored because you can't have } 2 \text { people on the screen. (Interview T1-SS) }\end{array}$ & $\begin{array}{l}\text { Working alone } \\
\text { Not making } \\
\text { decisions } \\
\text { Feeling bored }\end{array}$ & $\begin{array}{l}\text { Decision } \\
\text { making as part } \\
\text { of the gaming } \\
\text { experience }\end{array}$ \\
\hline $\begin{array}{l}\text { The only thing I see if you get started on a level, a second person may help you because if } \\
\text { I have a different idea what's going on one person get start. But if you're working alone } \\
\text { it's much faster, I think it's more enjoyable alone because you get to see what's going on. } \\
\text { (Interview T1-SS) }\end{array}$ & $\begin{array}{l}\text { Working alone is } \\
\text { more efficient and } \\
\text { more enjoyable }\end{array}$ & $\begin{array}{l}\text { Collaboration } \\
\text { as part of the } \\
\text { gaming } \\
\text { experience }\end{array}$ \\
\hline $\begin{array}{l}\text { My parents usually help me with making decisions } \\
\text { I cannot remember any major decisions that I had to take. (Interview T1-SS) }\end{array}$ & $\begin{array}{l}\text { Parental support in } \\
\text { decision making } \\
\text { experiences }\end{array}$ & $\begin{array}{l}\text { Experiences } \\
\text { with decision } \\
\text { making }\end{array}$ \\
\hline $\begin{array}{l}\text { Okay, give us an example of a decision-making process in this game! Think of a case } \\
\text { where you had to take a decision and you finally took a decision as a group. } \\
\text { S2T5: For example, if there was an argument between us and a guy and he insulted us } \\
\text { and he wanted us to do something that we didn't want to and we had a lot of choices like } \\
\text { insulting him, too or replying with a joke or changing the topic and we tried to decide } \\
\text { what seemed right, and then we had to be in the sentence. }\end{array}$ & $\begin{array}{l}\text { Examples of } \\
\text { decision making }\end{array}$ & $\begin{array}{l}\text { Experiences } \\
\text { with decision } \\
\text { making }\end{array}$ \\
\hline $\begin{array}{l}\text { R-Do you think gaming support you in developing skills for decision-making? } \\
\text { P-Yeah! It generated skills for decision-making because when you see someone in } \\
\text { experiencing decision-making, they don't just press random buttons and do whatever } \\
\text { they want. They have to stop to think before they press the button, they actually decide } \\
\text { which choice is right even if both choices seem correct they will think one has less } \\
\text { disadvantages and which more advantages, and then will act so to generate a lot of skills. }\end{array}$ & $\begin{array}{l}\text { Processes of } \\
\text { decision making } \\
\text { Stimulating decision } \\
\text { making }\end{array}$ & $\begin{array}{l}\text { Skills } \\
\text { development }\end{array}$ \\
\hline
\end{tabular}

similar populations. Even though this study took place in an after-school context because of administrative limitations, it is possible that the game is implemented in formal school contexts as well, especially as an interdisciplinary approach to health education that brings together biology, sex-education, and social sciences. The detailed description of the implementation ecosystem, the research method and data analysis, and the current research provided can help other practitioners and researchers to extract and utilize selected practices and suggestions for videogames implementation in educational settings.

\section{FINDINGS}

\section{Assertion 1: The Technical Affordances of the Game such as Sound, Usability, Rating System, and Visuals, are Vital Features that Defined the Quality of Play and Learning Experience}

The analysis of the students' post-implementation interviews provided evidence of how they assessed the technical affordances of the content of the game, related to design, graphics and sound. As the analysis shows, the visuals, sound and usability, influenced students' play experience, the game's attractiveness and students' game flow and engagement levels. An extract from an interview with a student illustrates that:

\section{R: Can you share some positive aspects of the game.}

S: Sure, the design was very nice! The graphics were ok, there are games with better graphics but for this game, these were ok. I also liked the sound.

\section{R: What was your overall game experience? \\ S: OK, it was a clear game and that helped us learn!}

\section{(Interview, student 11)}

The students appreciated the connection of voice and sound with the game's narrative. Many students made a special reference to the sound of the game, which they considered to be part of both their entertainment and learning process. One of the students stated:

I wanted to hear the story, sometimes there was noise in the room, but in my opinion, we learn by listening to the story; also, the game is more entertaining, that's what I think. (Interview, student 5)

In addition, some students simply liked the sound/music of the game, which made the play process more enjoyable.

\section{S1: Turn the volume down! \\ S2: No, I like it! \\ S1: You like the sound? \\ S2: Yes, I do! \\ S3: Come on, it's a very nice sound! (Videotaped group interaction)}


Overall, the students appeared to be positive about the technical characteristics of the game, and, more importantly, they believed these features enriched their play and learning experience:

\section{R: How do you compare games with other games that you play?}

S: I liked it, it was pretty and I found the environment creative; I liked the story. Compared to other games it could have better graphics, but I liked these ones, too, and I really had a lot of fun and learned a lot. (Interview, student 4)

An important technical characteristic of the game that students commented on was the game instructions and help functions. It seems that students, and, assumingly, all gamers, at least, at the initial stages of the game, need some support on its functionality and play requirements. This feature also relates to the appearance of a learning curve, until students become fully engaged with the game, which will be discussed in a following section. In this context, some students made a special reference to the importance of the game's instructions, and how these would support thoughtful play. One student said:

We found it at the end of the game after we discovered the instructions of the game. In the beginning we didn't understand what we were pressing and why, and time was passing. We also thought that with a strike you lose one star. But when we understood the game and completed a stage, we all screamed "Yees!" (Interview, student 7)

This quote provides evidence that understanding the game process and the purpose of the game's functionalities and scenarios, empowers conscious and thoughtful play and learning.

Another important feature of the game was its scoring and rating system. As some students noted, this feature empowered their engagement in the game. Additionally, the scoring and rating system contributed to their ability to reflect and comprehend the complexity and challenges of different themes and missions of the game. This reflection developed a task-oriented and thoughtful play process.

\section{$R$ : What was the most difficult part of the game?}

S: It was a stage referring to sex where we had to get 3 stars so that the game could move on. (Interview, student 2)

Moreover, the rating system and scoring led the game players to strategize and plan their moves, building up their critical thinking, collaboration and visioning skills.

\section{S1: Yeah!}

S2: Good job!

\section{S1: Show man!}

\section{S3: Wow! Both at the same time!}

S2: We need to get 3 stars! We need to get 3 stars to go to the next stage! Let's be careful with our choices! (Videotaped group interaction)

Finally, the scoring and rating system within a game constitutes the immediate awarding scheme of the students' success, and builds up on the overall game attractiveness and students' enthusiasm, providing a direct reflection on students' decisions within the game story-line. Moreover, the scoring system supports students' direct metacognition of their decisions and actions, while it guides students' scaffolding of knowledge.

Aligning the outcomes of the above data analysis, it can be argued that students found the technical affordances of the game attractive, adding up to the overall learning process and experience. Moreover, some of the technical characteristics of a game contributed to critical thinking, visioning, collaboration and negotiations skills development.

\section{Assertion 2: The Narrative of the Game Guided the Learning Game-play Experience of the Students}

Overall, the game's narrative and mini-game themes foster students' engagement and enthusiasm throughout the game, however, the extend of engagement and enthusiasms depended on how relevant that section of the story or theme is with students' personal experiences. An extract of the field-notes speaks to this:

\section{Students are becoming enthusiastic and dedicated again. The mission is about sexual pressure, and the challenge is to take a decision on how the reaction of someone experiencing that kind of behavior should be. They laugh, play and discuss, bringing themselves to the position of the game character, arguing what their decision would be in similar cases. (Field notes)}

The game narrative and its real-life relevance seems to be important for an educational game, as it contextualizes knowledge and empowers conscious participation and collaboration. Part of a games' narrative is also its characters. Students are attracted to the characters, something that contributes to their further engagement in the game:

\section{S1: Why are you reading it again?}

S3: I want to learn the whole story behind her! I like her a lot!

S1: Hahaha! He is going home to write stories for her!

S2: Yes, the story of his life! (Videotaped observation) 
Such an interest in the narrative and characters could be educational, providing hidden knowledge on health literacy, as students learn about the characters' background and actions. Through the process of analyzing and negotiating the development of a character, students are trying, through a social constructivist approach, to understand and give meaning to various attitudes of these characters. The analysis of the data showed that the majority of the students in different occasions linked their decisions within the game with real-life experiences. The extract below from an interview with a student illustrates that:

Student: That was very helpful, especially the parts, where she was a bit mean on some occasions. We won quicker because we talked like that. But personally, I don't think it's correct to reduce your attitude and character to the level of a person that talks in such a bad way, swears! I would avoid this. For example, a person may use irony and be aggressive. Are you going to do the same? There were many cases like this in the game!

Researcher: OK, this statement is very interesting!

S: I also like the part on the pressure because you notice how people press you, and you can make a decision on how to be excused, funny or mean!

\section{$R$ : Which are things you also face in your life, right?}

S: Yes, of course! Many times I think, what should I say now? Shall I adopt the same attitude? Shall I swear, too? (Interview, student 9)

On many occasions, the game story overlapped with students' real-life stories, offering authentic and transferable experiences to students, fulfilling the relevant element of social constructivist pedagogies. By associating themselves with the game characters students thoughtfully gain experience and understanding of the importance of health literacy issues. Essential to this progress is the connection of the game's characters' attitudes and actions regarding challenges students face in their real lives.

$R$ : Tell me a few things about your experience with the game, how did you collaborate and play?

S: It was very nice and linked with our lives, like the issue of sex, for example.

R: Nice! So did you learn anything that you would transfer to your life?

S: Yes, of course! You have to be careful of people and understand their character, like we did in the game, since you don't know how these people could influence you, especially in our days. (Individual interview, student 6)
Another important educational aspect of the implementation was the opportunity for collaborative and negotiated play, also a critical element of social constructivism that the game and implementation design provided. Students positively emphasized the emergence of a peer to peer learning process, which, as they also argued, contributed substantially to their ongoing engagement with the game play, the construction of knowledge, and the development of specific skills:

It was extremely pleasant to be able to collaborate with other students, and not be alone with the screen and try to think by myself. There were themes that I didn't know and had no experience of them, but other members of the team did, and this is how we progressed at different stages. Overall, it was a great experience, especially the team work. I have to say, that the game itself was very educational on things related to alcohol and sex, which are parts of our lives, so I wouldn't play this game alone. (Individual interview, student 1)

The students highly valued the content knowledge, as constructed through negotiated play and triggered by the game's learning themes. Also, the students argued about the importance of contextualizing acquired knowledge, and applying it to their real-life, and even transferring it to the wider network of friends.

\section{Assertion 3: Students Perceived that their Engagement in the Game Facilitated their Collaboration}

The analysis of the data showed that the students perceived their engagement in the game as educationally constructive and personally engaging, motivating and entertaining. Several extracts from the interviews we had with the students provide evidence of that:

\section{R: How was your overall game experience?}

S: We learned a lot and I enjoyed the collaboration. I liked the fact that we all had to listen to each other and work together, to be in the position to understand each other, why take these choices, and care about what they think. It was a very pleasant experience. (Interview, student 10)

Although the game was designed for individual play, the vast majority of students, during their interviews, stated that they would only play this game in a collaborative mode.

$R: O k$, did you enjoy playing the game with a team or would it have been better if you played individually?

S: It's more fun with partners; I wouldn't like to play this alone.

$R:$ What would be the difference? 
R: Ok, maybe it's slower when you play with the team but it's more fun. (Interview, student 2)

Students highly appreciated the teamwork, and the entertainment this experience offered them. Although they did note that collaborative mode delayed the play progress, since teammates needed to go through decision-making, the attractiveness of playing the game as a member of a group, surpassed any time-limitations of teamwork. This argument was also evident when students felt the need to compare it with previous experiences they had when playing the game individually:

In other games I played, I just chose a character and guided it to different missions, I had to think alone and take decisions. But in the game we played here, it was nicer, you could discuss with your friends and collaborate, complete missions together and have fun. (Interview, student 9)

Another important outcome of the analysis was the students' perception that the game design and format was highly supportive of collaborative play mode, referring specifically to the challenges of mini-games and the different thematic fields they covered:

And I think that the mini-games had a lot of collaborative work we needed to do because we all put down our ideas and sometimes disagreed, but we needed to agree in the end! Also, friends in the team knew different things about the game issues and we needed to discuss them. (Interview, student 4)

Collaboration, as designed for the case study implementation, and supported by the game format, infused an enthusiasm in the team's play process, almost in every session, even though some students continued complaining about repetitiveness. Based on our ethnographic observations, collaborative play appeared to be the driving force behind implementation and the primary element for students' ongoing engagement, having also in mind that many elements of the game were demotivating. It was amazing to see the teams' bonds deepen, how students built up their communication, and new forms of collaboration evolved. One of these new collaboration forms was intrateam collaboration. The groups started to consult each other, a progress, which in my mind, demonstrates skills of flexibility and adaptability to the game's challenges. An extract for our field notes offers an example of the types of collaboration that occurred during the implementation:

Students seemed to have the same enthusiasm as on the first day. Team 1 now seemed to have developed a more inclusive process of decision-making. Also, other teams seemed to value collaboration more, or learned how to collaborate. Team 4 composed of the 3 girls, remains the most enthusiastic, and best comprehends the game, while they never stopped discussing their options in the game. Another important aspect of game implementation is that the teams also collaborated with each other. Especially when a team moved ahead, other teams asked for validation or held onto their decisionmaking process. Teams cheered every time they completed a stage and, mostly, when they reached the stage of having 3 stars. For T4, that stage was when Kayla got pregnant and they had to take decisions. It was difficult for them to get 3 stars at that point, but the challenge deepened the team's internal and external collaboration in order to reach success. (Field notes)

As students moved on to the levels, more quality and content was attached to their collaboration, as they felt more comfortable to share and discuss various ideas and perceptions.

S1: What is that? No, no, noo! In the pool! I think staying in the pool is the right decision.

\section{S3: But, there are no key points.}

S1: Oh my God, you're crazy, do you see any key points? Stay in the pool, I think it's the right decision! You need refusal power to do this.

\section{S2: [reading through the instructions]}

Player 1: I think we should choose, "He wants me to get high with him"! I would do that!

S2: Let's skip and do something fun instead! Heyyy, I feel the power!

S1: We need to choose! I like the fun part!

S2: Nervous, illegal and health.

S1: Yes!

S2: What else? These 2 look very good!!! Owo!!

S3: Are you nervous...I don't know if you are doing this for the first time! (Videotaped group interaction)

Such direct discussions among students started to emerge as of the second implementation session. Between them, at least, they comprehended the importance of collaboration and opinion sharing to proceed with the game, developing, at once, their negotiation and critical thinking skills. In an interview we had with the student, he commented on this:

R: Tell me a few more things about your relationship to the other members of the team. How did you communicate?

S: As I said before, through the game you could see what was on everyone's minds, each other's general knowledge and knowledge about sexual education, alcohol and drugs. We learned from each other, as well 
as becoming connected as friends in real-life. We are more open to each other and trust each other now.I think the team was the most important thing and what kept the fun and game going, yeah! (Interview, student 11)

Concluding from the above, both the game and intervention design appeared to be critical factors in promoting collaborative play. As the students shared, the nature of the mini-games, the thematic focus of the game, and the team-based implementation of the game supported their collaboration in playing the game.

\section{CONCLUSIONS AND IMPLICATIONS}

\section{Technical Affordances}

The technical affordances of any game are critical both for the target groups and the stakeholders, and must be addressed as primary challenges (Naismith al., 2004; Strack, Magill, \& McDonagh, 2004), when designing a game implementation. Therefore, game designers, instructional designers and educators must be fully aware of the digital literacy levels and familiarity of their target groups and stakeholders with mobile videogames. Moreover, game developers, teachers and instructional designers, need to align the visuals and sounds of the game with the overall pedagogical framework and game theme. This way, they will maximize the game's contextualization, improve the gaming experience and attract students' mindful engagement (Arnab et al., 2013). Games maximize the motivation of students to learn when they provide an environment of mystery that triggers their fantasy. Such features are associated with the visuals' design, sounds and game storyline (Sherry, Lucas, Greenberg, \& Lachlan, 2006; Wilson, Bedwell, Lazzara, Salas, Burke, Estock, \& Conkey, 2009). As was observed during the implementation, the game graphics and sounds were attractive to students and helped them become attached to the game scenario. Therefore, game, graphic and instructional designers need to collaborate, to align the abovementioned technical affordances of the game with its pedagogical purposes and learning objectives.

Moreover, based on the data analysis from the videorecorded observations, the game's rating system has been a vital component of student control over their game play, thoughtful engagement and skills development. Therefore, interested practitioners when designing or using games will need to match the game's rating system with the play and the learning process of the users (McCallum, 2012). Another important element of the games, linked with its affordances, are its play rules, guidelines and feedback. The play rules for educational games are essential in providing the space and opportunity for gamers to experiment without worrying that if they make an error they will have to restart the game. This way, they will be able to try various reasoning paths, which are associated with knowledge contextualization and game play authenticity (McGonigal, 2011; O'Neil, Wainess \& Baker, 2005). With regards to the game guidelines observed in this research, as on many occasions, are essential for empowering students' mindful engagement. Lastly, students greatly appreciated the feedback they were getting from the game and the various pop-ups regarding their next steps, errors or new knowledge. Direct feedback adds to the authenticity of the game play, empowers the game play learning process, and supports students' thoughtful participation (Collins \& Halverson, 2010).

In addition, game design and development should adopt an interdisciplinary approach in which technical affordances will be aligned with the learning objectives and the contextualization of skills and knowledge to be developed, through visuals, sounds, play mode and narrative (Stokes, 2012). The game narrative and storytelling are components that carry all game affordances associated with the learning and educational directions of the game (Flyvbjerg, 2006). Hence, the designers of online games must not only approach the game design process as if constructing artefacts, but more like assembling a "social practice" (Amory, 2007, p. 67), or a social ecosystem.

Lastly, research in educational games directly connects the element of fantasy with the game narrative. Therefore, a well-situated story will provide the opportunity for students to develop their transferability, visualization and problem solving skills (Amory, 2007). The story of a game must evolve through a variety of short missions, tasks and mini-games, have different chapters and episodes, where the player will be able to make various choices and face a number of challenges. Especially, in a collaborative mode, this will trigger decision-making processes, shared visioning and planning, collective metacognition and conscious engagement (Dickey, 2007).

\section{Negotiated Play and Decision-making Skills}

One of the research questions of the study was to examine how the game facilitated the decision- making process and how the overall case study design and implementation contributed to the skills development process. In terms of decision-making, as shown in the findings, the PlayForward was not fully efficient in facilitating a quality decision-making process. Students, although negotiating to make a decision, their arguments didn't include any rhetoric related to ideas, or opinions about the game theme. The repetition of missions led students, during the last sessions of the game, to make decisions mechanically, with limited content-related argumentation. Also, the challenges, in many cases, were camouflaged close-ended questions, which demotivated students to investigate likely answers or elaborate an opinion. For a game to trigger a 
negotiation of ideas and raise content-related argumentation, it must provide features of research outside the game (i.e., through the internet), or provide missions with open-ended challenges (Linehan Lawson, Doughty, \& Kirman, 2009). To conclude, the games' design and development must be more sophisticated, along with a multimodal approach to learning, including follow up reflections on the game play experience (Whitton \& Hollins, 2008). Nevertheless, the students engaged consciously in decision-making processes, where they developed a series of skills, including being creative in reaching a consensus. Such practice of reaching a final decision, included voting, assigning a leader to make a final decision, or timely negotiation. These adaptations and flexibilities of students following multiple paths in reaching a final decision are characteristics of effective educational games (Robertson \& Howells, 2008).

Concluding, in an evolving globalized world, health literacy is of paramount importance, and the overall educational system has to become compatible with the learning needs of citizens, who need to be networked, engaged and informed (Hernandez, 2013). Therefore, any health literacy education initiative has be needsoriented and provide opportunities for collaboration, peer-to-peer learning, and problem solving, in an era of sophisticated, mobile and personalized information and communication technologies.

\section{ACKNOWLEDGEMENTS}

The game used for this study, PlayForward was developed at the play2PREVENT Lab at the Yale Center for Health \& Learning Games, Yale University School of Medicine, and is funded by the Eunice Kennedy Shriver National Institute of Child Health and Human Development. We would like to thank Lynn E. Fiellin, M.D., Associate Professor of Medicine and the Yale Child Study Center, Director, play2PREVENT Lab at the Yale Center for Health \& Learning Games, Yale University School of Medicine and Kimberly Hieftje, Ph.D., Research Scientist, Deputy Director, play2PREVENT Lab at the Yale Center for Health \& Learning Games, Yale University School of Medicine. The study was conducted in the framework of the collaboration between the Yale School of Public Health and CARDET (www.cardet.org).

\section{REFERENCES}

Amory, A. (2007). Game object model version II: a theoretical framework for educational game development. Educational Technology Research and Development, 55(1), 51-77. https:/ / doi.org/10.1007/ s11423-006-9001-x

Arnab, S., Brown, K., Clarke, S., Dunwell, I., Lim, T., Suttie, N., Louchart, S., Hendrix, M., \& De Freitas, S. (2013). The development approach of a pedagogically-driven serious game to support Relationship and Sex Education within a classroom setting. Computers \& Education, 69, 15-30. https:// doi.org/10.1016/j.compedu.2013.06.013

Blumberg, F. C., Almonte, D. E., Anthony, J. S., \& Hashimoto, N. (2013). 19 Serious Games: What Are They? What Do They Do? Why Should We Play Them? (p. 334). The Oxford Handbook of Media Psychology, Oxford: Oxford University Press. https:// doi.org/10.1093/oxfordhb/978019539880 9.013.0019

Collins, A., \& Halverson, R. (2010). The second educational revolution: Rethinking education in the age of technology. Journal of computer assisted learning, 26(1), 18-27. https://doi.org/10.1111/ j.1365-2729.2009.00339.x

Cunningham, D., \& Duffy, T. (1996). Constructivism: implications for the design and delivery of instruction. In D. Jonassen (Ed.), Handbook of research for educational communications and technology (pp. 170198). London: Prentice Hall.

Dickey, M. D. (2007). Game design and learning: A conjectural analysis of how massively multiple online role-playing games (MMORPGs) foster intrinsic motivation. Educational Technology Research and Development, 55(3), 253-273. https:// doi.org/10.1007/s11423-006-9004-7

Fiellin, L. E., Hieftje, K., Edelman, E. J., \& Camenga, D. R. (2013). Play To Prevent Can Video Games Make Kids Healthier? Footnote ${ }^{1}$. Retrieved from http:/ / footnote1.com/can-video-games-makekids-healthier/

Flyvbjerg, B. (2006). Five misunderstandings about casestudy research. Qualitative inquiry, 12(2), 219-245. https:/ / doi.org/10.1177/1077800405284363

Fuchslocher, A., Niesenhaus, J., \& Krämer, N. (2011). Serious games for health: An empirical study of the game "Balance" for teenagers with diabetes mellitus. Entertainment Computing, 2(2), 97-101. https://doi.org/10.1016/j.entcom.2010.12.001

Galotti, K. M. (2002). Making decisions that matter: How people face important life choices. Mahwah, New Jersey: Lawrence Erlbaum Associates Publishers.

Glaser, B. G. (1978). Theoretical sensitivity. San Francisco, California: The Sociology Press.

Hense, J., \& Mandl, H. (2014). Learning in or with Games?. In Digital Systems for Open Access to Formal and Informal Learning (pp. 181-193). New York, NY: Springer International Publishing. https:/ / doi.org/10.1007/978-3-319-02264-2_12

Hernandez, L. M. (Ed.). (2013). Health Literacy: Improving Health, Health Systems, and Health Policy Around the World: Workshop Summary. National Academies Press. 
Hieftje, K., Duncan, L. R., \& Fiellin, L. E. (2014). Novel methods to collect meaningful data from adolescents for the development of health interventions. Health promotion practice, 15(5), 714722. https:/ / doi.org/10.1177/1524839914521211

Kearney, M., Schuck, S., Burden, K., \& Aubusson, P. (2012). Viewing mobile learning from a pedagogical perspective. Research in learning technology, 20.14406. https://doi.org/10.3402/ rlt.v20i0.14406

Kim, S. H., Mims, C., \& Holmes, K. P. (2006). An introduction to current trends and benefits of mobile wireless technology use in higher education. AACE journal, 14(1), 77-100.

Koutromanos, G., \& Avraamidou, L. (2014). The use of mobile games in formal and informal learning settings: A review of the literature. Educational Media International, 51(1), 49-65. https://doi.org/ 10.1080/09523987.2014.889409

Lankshear, C., \& Knobel, M. (2011). New Literacies: Everyday Practices and Social Learning: Everyday Practices and Social Learning. McGraw-Hill International.

Lenhart, A., Kahne, J., Middaugh, E., Macgill, A. R., Evans, C., \& Vitak, J. (2008). Teens, Video Games, and Civics: Teens' Gaming Experiences Are Diverse and Include Significant Social Interaction and Civic Engagement. Washington DC: Pew Internet $\mathcal{E}$ American Life Project.

Linehan, C., Lawson, S., Doughty, M., \& Kirman, B. (2009). There's no 'I' in 'Emergency Management Team: ' Designing and evaluating a serious game for training emergency managers in group decision making skills. In Proceedings of the 39th Conference of the Society for the Advancement of Games $\mathcal{E}$ Simulations in Education and Training (pp. 20-27). Innovation North-Leeds Metropolitan University.

Martin, S., Diaz, G., Sancristobal, E., Gil, R., Castro, M., \& Peire, J. (2011). New technology trends in education: Seven years of forecasts and convergence. Computers \& Education, 57(3), 18931906. https://doi.org/10.1016/j.compedu.2011.04. 003

McCallum, S. (2012). Gamification and serious games for personalized health. Stud Health Technol Inform, 177, 85-96.

McGonigal, J. (2011). Reality Is Broken: Why Games Make Us Better and How They Can Change the World. London: Penguin.

Merriam, S. B. (2009). Qualitative Research: a guide to design and interpretation. San Francisco, California: Jossey-Bass.

Mishra, R. K. (2014). Social constructivism and teaching of social science. Journal of Social Studies Education
Research, 5(2), 1-13. https://doi.org/10.17499/ jsser.22283

Montanaro, E., Fiellin, L. E., Fakhouri, T., Kyriakides, T. C., \& Duncan, L. R. (2015). Using videogame apps to assess gains in adolescents' substance use knowledge: new opportunities for evaluating intervention exposure and content mastery. Journal of medical Internet research, 17(10), e245. https:// doi.org/10.2196/jmir.4377

Montgomery, K., Gottlieb-Robles, B., \& Larson, G. O. (2004). Youth as e-citizens: Engaging the digital generation. Washington DC: Center for Social Media School of Communication, American University.

Muntean, C. I. (2011, October). Raising engagement in elearning through gamification. In Proc. 6th International Conference on Virtual Learning ICVL (pp. 323-329).

Naismith, L., Lonsdale, P., Vavoula, G. N., \& Sharples, M. (2004). Mobile technologies and learning. hal00190143.

Olson, C. K. (2010). Children's motivations for video game play in the context of normal development. Review of General Psychology, 14(2), 167-179. https:/ / doi.org/10.1037/a0018984

O'Neil, H. F., Wainess, R., \& Baker, E. L. (2005). Classification of learning outcomes: Evidence from the computer games literature. The Curriculum Journal, 16(4), 455-474. https://doi.org/10.1080/ 09585170500384529

Park, Y. (2011). A pedagogical framework for mobile learning: Categorizing educational applications of mobile technologies into four types. The International Review of Research in Open and Distributed Learning, 12(2), 78-102. https:/ / doi.org/ 10.19173/irrodl.v12i2.791

Patton, M. (2002). Qualitative research E evaluation methods (3rd ed.). London, UK: Sage.

Raphael, C., Bachen, C., Lynn, K. M., Baldwin-Philippi, J., \& McKee, K. A. (2010). Games for civic learning: A conceptual framework and agenda for research and design. Games and Culture, 5(2), 199-235. https:/ / doi.org/10.1177/1555412009354728

Ray, B., Caroline Faure EDD, A. T. C., \& Kelle, F. (2013). Using social impact games (SIGS) to support constructivist learning: Creating a foundation for effective use in the secondary social studies education. American Secondary Education, 41(2), 60

Robertson, J., \& Howells, C. (2008). Computer game design: Opportunities for successful learning. Computers $\mathcal{E}$ Education, 50(2), 559-578. https:// doi.org/10.1016/j.compedu.2007.09.020

Schugurensky, D., \& Myers, J. P. (2008). Informal Civic Learning Through Engagement in Local Democracy: The Case of the Seniors' Task Force of Healthy City Toronto. In Learning through 
Community (pp. 73-95). Dordrecht, Netherlands: Springer. https://doi.org/10.1007/978-1-40206654-2_5

Sherry, J. L., Lucas, K., Greenberg, B. S., \& Lachlan, K. (2006). Video game uses and gratifications as predictors of use and game preference. Playing video games: Motives, responses, and consequences. In P. Vorderer \& J. Bryant (Eds.), Playing video games: Motives, responses, and consequences (pp. 213-224). Lawrence Erlbaum Associates Publishers.

Shin, N., Norris, C., \& Soloway, E. (2011). Mobile Gaming Environment: Learning and motivational effects. In P. Felicia (Ed.), Handbook of research on improving learning and motivation through educational games: Multidisciplinary approaches (pp. 467-481). Hershey, PA: Information Science Reference. https://doi.org/10.4018/978-1-60960-495-0.ch022

Stake, R. E. (2011). Qualitative research: Studying how things work. New York, NY: The Guilford Press.

Stokes, B. (2012). Restructuring civic engagement: Meaningful choice and game design thinking. In A. Delwiche \& J. J. Henderson (Eds.), The Participatory Cultures Handbook. New York, NY: Routledge.
Strack, R. W., Magill, C., \& McDonagh, K. (2004). Engaging youth through photovoice. Health promotion practice, 5(1), 49-58. https://doi.org/ $10.1177 / 1524839903258015$

Walker, K. (2006). Introduction: Mapping the landscape of mobile learning. In M. Sharples (Ed.), Big issues in mobile learning: Report of a workshop by the kaleidoscope network of excellence mobile learning initiative. University of Nottingham.

Whitton, N., \& Hollins, P. (2008). Collaborative virtual gaming worlds in higher education. Research in learning technology, 16(3). 221-229. https:/ / doi.org/ 10.3402/rlt.v16i3.10900

Wilson, K. A., Bedwell, W. L., Lazzara, E. H., Salas, E., Burke, C. S., Estock, J. L., \& Conkey, C. (2009). Relationships between game attributes and learning outcomes review and research proposals. Simulation \& Gaming, 40(2), 217-266. https:/ / doi.org/10.1177/1046878108321866

World Health Organization Regional Office for Europe (WHO; 2013). Standards for Sexuality Education in Europe. Federal Centre for Health Education (BZgA): Cologne.

\section{http://www.ejmste.com}

